\title{
Descriptions and validation of the names of some high-rank syntaxa in the European Asplenietea trichomanis and Polypodietea
}

\author{
Ladislav Mucina $^{1}$ \& Jean-Paul Theurillat ${ }^{2}$
}

\begin{abstract}
Mucina, L. \& Theurillat, J.-P. Descriptions and validation of some high-rank syntaxa in the European Asplenietea trichomanis and Polypodietea. Lazaroa 36: 75-78 (2015).

The paper presents the description of one new order (Asplenietalia septentrionalo-cuneifolii) and two new alliances (Arenarion bertolonii and Physoplexido comosae- Saxifragion petraeae). In addition, the syntaxon Asplenietalia lanceolato-obovati is here formally raised to the order level and the name Hypno-Polypodietalia vulgaris is validated.
\end{abstract}

Keywords: alliance, Asplenietea trichomanis, chasmophytic vegetation, order, phytosociology, Polypodietea, Southern Alps, syntaxonomy, validation, Western Europe.

Resumen: Mucina, L. \& Theurillat, J.-P. Descripciones y validaciones de algunos sintaxa de alto rango de Asplenietea trichomanis y Polypodietea en Europa. Lazaroa 36: 75-78 (2015).

En este trabajo se describe un nuevo orden (Asplenietalia septentrionalo-cuneifolii) y dos nuevas alianzas (Arenarion bertolonii and Physoplexido comosae-Saxifragion petraeae) dentro de Asplenietea. Además Asplenietalia lanceolato-obovati es formalmente propuesto como orden y el nombre Hypno-Polypodietalia vulgaris es validado.

Palabras clave: alianza, Asplenietea trichomanis, vegetación casmofítica, orden, fitosociología, Polypodietea, Alpes del sur, sintaxonomía, validación, oeste de Europa.

\section{INTRODUCTION}

Although the European chasmophytic (rockcrevice) vegetation of the Asplenietea trichomanis and the Polypodietea does not occupy large areas, it is yet one of the most diverse vegetation types in Europe, comprising plant communities of low diversity, but showing high levels of local/regional endemism. Biogeography and geology play a major role in structuring of the Asplenietea trichomanis as reflected in 13 orders and 61 alliances recognised as welldefined syntaxa for Europe (MuCINA \& al., submitted).
This paper was motivated by the synthetic assessment of the European vegetation to be shortly published as the EuroVegChecklist (Mucina \& al., submitted) and should serve to solve several nomenclatural and syntaxonomic issues in the Asplenietea trichomanis. References to articles of the International Code of Phytosociological Nomenclature (ICPN) follow WeBER \& al. (2000). Nomenclature of the taxa follows the Euro+Med PlantBase (http://www.emplantbase.org/home.html) if not indicated otherwise.

\footnotetext{
${ }^{1}$ School of Plant Biology, The University of Western Australia, 35 Stirling Highway, Crawley, WA 6009, Perth, Australia. Department of Geography \& Environmental Studies, Stellenbosch University, Private Bag X1, Matieland 7602, Stellenbosch, South Africa.

Department of Botany and Microbiology, College of Science, King Saud University, P.O. Box 2455, Riyadh 11451, Saudi Arabia.

${ }^{2}$ Centre Alpien de Phytogéographie, Fondation J.-M. Aubert, Case postale 71, CH-1938 Champex-Lac, Switzerland.

Section of Biology, University of Geneva, Case postale 60, CH-1292 Chambésy, Switzerland.
} 


\section{DESCRIPTION AND VALIDATION OF THE NAMES OF SYNTAXA OF THE ASPLENIETEA TRICHOMANIS}

Asplenietalia septentrionalo-cuneifolii ord. nov. hoc loco

(Asplenietea trichomanis)

TYPE: Holotypus hoc loco: Asplenion septentrionalis Gams ex Oberd. 1938 (OBERDORFER, 1938: 163).

DiAgNostic tAXA OF THE ORDER: Asplenium cuneifolium, A. marinum, A. septentrionale.

The vegetation of siliceous and ultramafic rock crevices at low altitudes of the temperate and boreal Europe has been in the past mostly classified within the Androsacetalia vandellii (e.g. Oberdorfer \& al., 1967; Mucina, 1993: 260; Theurillat \& al., 1995; Valachoviè \& al., 1995) - the home of the high-altitude chasmophytic vegetation on siliceous substrates in cool-temperate (nemoral) and boreal Europe. The latter syntaxon is characterised by a high number of local and regional endemics, while the rock-crevice plant communities of lower altitudes are species-poor and usually dominated by widely distributed, yet ecologically specialised species such as Asplenium septentrionale. The name 'Asplenietalia septentrionalis' for this syntaxon is not available since it has been suggested as a 'better name' (ICPN art. 29a) for the name Androsacetalia vandellii (OBERDORFER \& al., 1967: 12; LOISEL, 1970: 170).

SyntaXonomy: Alliances included in the Asplenietalia septentrionalo-cuneifolii:

Asplenion marini Rivas-Martínez et Izco in Rivas-Martínez et al. 2002 (RIVAs-MarTíNEz \& al., 2002: 47)

Asplenion septentrionalis Gams in Oberd. 1938 (OBERDORFER, 1938: 163-165)

Asplenion serpentini Br.-Bl. et Tx. ex Eggler 1955 (EGGLER, 1955: 66)

Pohlio crudae-Asplenion septentrionalis Brullo et Siracusa in Brullo et al. 2001 (BRULlo \& al., 2001: 173)

Thalictro foetidi-Asplenion Onipchenko et Gorbachevskaya in Onipchenko 2002 (ONIPCHENKO, 2002a: 44, 2002b: 89).
Asplenietalia lanceolato-obovati (Loisel 1970) Theurillat et Mucina ord. nov. hoc loco (Asplenietea trichomanis)

ORIGINAL SYNTAXONOMIC CONCEPT: 'Sous-ordre des Asplenietalia lanceolato-obovati' (Loisel, 1970: 170-171).

TYPE: Holotypus: Asarinion rupestre Br.-Bl. in Meier et Br.-Bl. 1934 (see below).

Diagnostic taxa of the order: Allosurus pteridoides (syn. Cheilanthes fragrans), Bufonia macropetala subsp. willkommiana, Phagnalon saxatile.

Here the name Asplenietalia lanceolato-obovati Loisel 1970 (originally described in the rank of suborder) is raised at the order level. It includes the plant communities of rock faces on siliceous substrate at low elevation in the Central and Western Mediterranean region.

We select the name Asarinion rupestre Br.-Bl. in Meier et Br.-Bl. 1934 (Meier \& Braun-Blanquet, 1934: 41; ICPN art. 34) as the lectotype (lectotypus hoc loco) of the name Asplenienalia lanceolato-obovati Loisel 1970, the correct name for the alliance being the name Asarinion rupestre (Br.-Bl. in Meier et Br.-Bl. 1934) Br.-Bl. in Br.-Bl. et al. 1952.

Alliances included in the Asplenietalia lanceolato-obovati:

Antirrhinion asarinae (Br.-Bl. in Meier et Br.B1. 1934) Br.-Bl. in Br.-Bl. et al. 1952 (BRAUNBlANQUET \& al., 1952: 30-31)

Cheilanthion hispanicae Rivas Goday et al. 1956 (Rivas GodAY \& al., 1956: 341-344)

Linarion caprariae Foggi et al. 2006 (FoGGI \& al., 2006: 29-31, Tab. 14)

Dianthion rupicolae Brullo et Marcenò 1979 (Brullo \& Marcenò, 1979: 133, 139).

Arenarion bertolonii Gamisans all. nov. hoc loco (Asplenietalia glandulosi, Asplenietea trichomanis) SYNONYM: Arenarion bertolonii Gamisans 1991 (ICPN art. 8).

TYPE: Holotypus hoc loco: Asplenio rutae-murariaeArenarietum bertolonii Gamisans 1975 (GAMISANS, 1975: 37-38).

DiagnOSTIC TAXA OF THE ALLIANCE: Arabis collina, Arenaria bertolonii, Asplenium ruta-muraria, Sesleria insularis subsp. insularis. 
In GAMISANS (1991: 357), the new alliance 'Arenarion bertolonii' includes two associations, such as the Asplenio rutae-murariae-Arenarietum bertolonii Gamisans 1975 and the new association 'Elymo corsici-Ptychotetum saxifragae (Litard. 1928) Gamisans 1991', (see GAMISANS, 1991). Since no diagnostic species were listed for the alliance, the original diagnosis of the name remained insufficient (ICPN art. 8). Therefore, we validate the syntaxon name by listing those diagnostic species mentioned above.

\section{Physoplexido comosae-Saxifragion petraeae all. nov. hoc loco}

(Potentilletalia caulescentis, Asplenietea trichomanis)

SYNONYMS: Androsaco-Drabion tomentosae Wraber 1970 (ICPN art. 29); PhyteumatoSaxifragion petraeae Mucina in Šilc et Čarni 2012 (IPCN arts. 2b \& 5).

CORRESPONDING SYNTAXONOMIC CONCEPT: Phyteumato-Saxifragenion petraeae Sutter 1969 (ICPN art. 3b); (see SutTER, 1969).

CORRESPONDING SYNTAXON (SUBALlianCE): Physoplexido comosae-Saxifragenion petraeae Theurillat in Theurillat et al. 1995

Type: Holotypus hoc loco: PhyteumatoAsplenietum seelosii E. Pignatti et S. Pignatti 1961 (Pignatti \& Pignatti, 1961: 698).

Diagnostic taXa of the alliance: Arenaria huteri, Asplenium ruta-muraria subsp. dolomiticum, Bupleurum petraeum, Campanula carnica, C. morettiana, C. raineri, Daphne alpina, Minuartia graminifolia, Moehringia dielsiana, M. glaucovirens, M. markgrafii, M. villosa, Paederota bonarotta, P. lutea, Physoplexis comosa, Phyteuma scheuchzeri subsp. columnae, Potentilla nitida, Primula spectabilis, $P$. tyrolensis, Saxifraga arachnoidea, S. crustata, S. facchinii, S. mutata, S. petraea, S. presolanensis, S. squarrosa, S. tombeanensis, S. vandellii, Silene saxifraga, S. veselskyi, Spiraea decumbens subsp. tomentosa and Xerolekia speciosissima.

This alliance had to be described and the name introduced became necessary because of the illegitimacy of the name Androsaco-Drabion tomentosae that is a nomen superfluum since Wraber (1970) included the Androsacetum helveticae (the holotype of an earlier valid syntaxonomic concept - the Potentillion caulescentis Braun-Blanquet in Br.-Bl. et Jenny 1926) into the protologue of the Androsaco-Drabion tomentosae. Here we designate the Phyteumato-Asplenietum seelosii E. Pignatti et S. Pignatti 1961 as the holotypus of the new alliance Physoplexido comosaeSaxifragion petraeae. The diagnostic species of the alliance are mentioned above.

\section{VALIDATION OF THE NAME HYPNO-POLYPODIETALIA VULGARIS (POLYPODIETEA)}

\section{Hypno-Polypodietalia vulgaris Jurko et Peciar ex Mucina et Theurillat ord. nov. hoc loco}

SYNONYMS: Hypno-Polypodietalia vulgaris Jurko et Peciar 1963 (ICPN arts. 2b \& 8) (see Jurko \& PeCIAR, 1963); Hypno-Polypodietalia vulgaris Jurko et Peciar ex Brullo et al. 2001 (ICPN art. 5)

TYPE: Holotypus hoc loco: Hypno-Polypodion Mucina 1993 (Mucina, 1993: 267)

DiAgNOSTIC TAXA OF THE ORDER: Bartramia pomiformis Hedw., Dryopteris dilatata, Hypnum cupressiforme L., Oxalis acetosella, P. vulgare

In JuRKo \& PeCIAR (1963: 208), the name 'Hypno-Polypodietalia' is lacking a sufficient diagnosis (ICPN arts. 2b \& 8) as no alliance was indicated to include the new, validly published association 'Hypno-Polypodietum Jko. et Pec. ass. nov.'. Here we designate the Hypno-Polypodion Mucina 1993 as the holotypus hoc loco to validate the name Hypno-Polypodietalia. The diagnostic species of the alliance are mentioned above.

\section{ACKNOWLEDGEMENTS}

We greatly acknowledge the help of the following institutions and colleagues, respectively, in providing less accessible literature: the library of the Conservatoire et Jardin botaniques of the City of Geneva, the Conservatoire botanique national of Bailleul, Nicolas Fumeaux and Séverine Peckeu. 


\section{BIBLIOGRAPHY}

Braun-Blanquet, J., Roussine, N. \& Nègre, R. - 1952Les groupements végétaux de la France Méditerranéenne - C.N.R.S., Montpellier, FR.

Brullo, S. \& Marcenò, C. —1979- Dianthion rupicolae nouvelle alliance sud-tyrrhenienne des Asplenietalia glandulosi. - Doc. Phytosociol. N.S. 4: 131-146.

Brullo, S., Scelsi, F. \& Spampinato, G. —2001 - La vegetazione dell'Aspromonte, Studio fitosociologico Laruffa Editore, Villa S. Giovanni, IT.

Eggler, J. - 1955 - Ein Beitrag zur Serpentinvegetation in der Gulsen bei Kraubath in Obersteiermark - Mitt. Naturwiss. Vereines Steiermark 85: 27-72.

Foggi B., Cartei, L., Pignotti, L., Signorini, M.A., Viciani, D., Dell'Olmo, L. \& Menicagli, E. —2006 - Il paesaggio vegetale dell'Isola d'Elba (Arcipelago Toscano). Studio di fitosociologia e cartografico - Fitosociologia 43(1), Suppl. 1: 3-95.

Gamisans, J. — 1975 — La végétation des montagnes corses - Thèse de Doctorat d'Etat ès Science, Université de Marseille, FR.

Gamisans, J. —1991 - La végétation de la Corse Conservatoire et Jardin botaniques, Genève, $\mathrm{CH}$.

Jurko, A. \& Peciar, V. — 1963 - Pflanzengesellschaften an schattigen Felsen in der Westkarpaten - Vegetatio 11: 199-209.

Loisel, R. —1970 - Contribution à l'étude des groupements rupicoles calcifuges - Anales Inst. Bot. Cavanilles 26: 165-196.

Meier, H. \& Braun-Blanquet, J. —1934- Prodrome des groupements végétaux. 2. Asplenietales rupestres Groupements rupicoles. Comité International du Prodrome Phytosociologique, Montpellier, FR.

Mucina, L. - 1993 - Asplenietea trichomanis - In: Grabherr, G. \& Mucina, L. (Eds.). Die Pflanzengesellschaften Österreichs. Teil II - Gustav Fischer Verlag, Jena. Pp. 241-275.

Mucina, L., Bültmann, H., Dierßen, K., Theurillat, J.P., Raus, T., , Čarni, A., Šumberová, K., Willner, W., Dengler, J., Gavilán, R., Chytrý, M., Hájek, M., Di Pietro, R., Lakushenko D., Pallas, J., Daniëls, F.J.A., Bergmeier, E., Santos Guerra, A., Ermakov, N., Valachovič, M., Schaminée, J.H.J., Lysenko, T., Didukh, Y.P., Pignatti, S., Rodwell, J.S., Capelo, J., Weber, H.E., Solomeshch, A., Dimopoulos, P., Aguiar, C., Hennekens, S.M. \& Tichý, L. —submittedVegetation of Europe: Hierarchical floristic classification system of vascular plant, bryophyte, lichen, and algal communities - Appl. Veg. Sci. (submitted).
Oberdorfer, E. —1938 - Ein Beitrag zur Vegetationskunde des Nordschwarzwaldes - Beitr. Naturk. Forsch. Südwestdeutschland 3: $150-270$.

Oberdorfer, E., Görs, S., Korneck, D., Lohmeyer, W., Müller, T., Philippi, G. \& Seibert, P. —1967Systematische Übersicht der westdeutschen Phanerogamen- und Gefäßkryptogamen-Gesellschaften - Schrif. Veg. 2: 7-240.

Onipchenko, V.G. - 2002a- Alpine vegetation of the Teberda Reserve, the northwestern Caucasus - Veröff. Geobot. Inst. ETH, Stiftung Rübel 130: 1-168.

Onipchenko, V.G. - 2002b- Tipifikatiya nekotorykh assotsiatsii skal'nogo-osypnoi rastitel'nosti severozapadnogo Kavkaza. (Typification of some rock and scree vegetation of the north-western Caucasus) Biul. Moskov. Obshsch. Ispytat. Prir., Otd. Biol. 107: 88-89.

Pignatti, E. \& Pignatti, S. —1961('1960’) — Una associazione rupestre endemica nelle Dolomiti Orientali (Phyteumato-Asplenietum seelosii) all'estremo orientale della sua area - Nuovo Giorn. Bot. Ital. N.S. 66(1960): 697-701. (effective publication: 1961)

Rivas Goday, S. \& cols. —1956('1955') — Aportaciones a la Fitosociología hispaníca. (Proyectos des communidates hispanícas) - Anales Inst. Bot. Cavanilles 13: 335-422. (effective publication: April 1956)

Rivas-Martínez, S., Díaz, T. E., Fernández-González, F., Izco, J., Loidi, J., Lousã, M. \& Penas, A. -2002Vascular plant communities of Spain and Portugal. Addenda to the syntaxonomical checklist of 2001 Itinera. Geobot. 15: 5-922.

Sutter, R. - 1969- Ein Beitrag zur Kenntnis der soziologi-schen Bindung Süd-Südostalpiner Reliktendemismen - Acta Bot. Croat. 28: 349-366.

Theurillat, J.P., Aeschimann, D., Küpfer, P. \& Spichiger, R. - 1995 - The higher vegetation units of the Alps Coll. Phytosociol. 23: 189-239.

Valachovič, M., Ot'ahel'ová, H., Stanová, V. \& Maglocký, Š. —-1995- Rastlinné spoločenstvá Slovenska. 1. Pionierska vegetácia. (Plant communities of Slovakia. 1. Pioneer vegetation.) — Veda, Bratislava, SK. (in Slovak)

Weber, H.E., Moravec, J. \& Theurillat, J.P. -2000International Code of Phytosociological Nomenclature. 3rd ed. - J. Veg. Sci. 11: 739-768.

Wraber, T. - 1970 - Die vegetation der subnivalen Stufe in den Julischen Alpen - Mitt. Ostalpin-Dinarischen Pflanzensoziol. Arbeitsgem. 11: 249-256. 